\title{
UPAYA PENINGKATAN KOMPETENSI GURU DALAM MENYUSUN SILABUS DAN RENCANA PELAKSANAAN PEMBELAJARAN (RPP) MELALUI SUPERVISI AKADEMIK YANG BERKELANJUTAN DI SMK NEGERI 4 PADANGSIDIMPUAN
}

\author{
Budiman Sihombing \\ Pengawas Madya SMK Dinas Pendidikan Provinsi Sumatera Utara \\ budimansihombing@gmail.com
}

DOI : 10.31604/ptk.v1i3.185-191

\begin{abstract}
This research was to look at the percentage of academic supervision the school principal can raise the competence of teachers in the preparation of the syllabus and the RPP. The location of the research is on the CMS State 4 Padangsidimpuan in Jln. Desa Plantations Pijorkoling plantations of Kec. Padangsidimpuan Southeast Of The City Padangsidimpuan. Implementation time is planned for one month starting August 1 to October 30, 2015. This research was carried out on its writers, and writers assisted by curriculum Developers Team SMK Negeri 4 Padangsidimpuan consisting of the principal, Curriculum, and Waka Waka Studentship. This research was conducted with the research methods class action that lasted for two cycles. Each cycle consists of the stages of planning, implementation, observation, and reflection. The results obtained, namely the increasing number of good teachers syllabus of $31 \%$ to $83 \%$ after academic supervision. Also, the number of RPP good quality also increased from $31 \%$ to $89 \%$. Increased competency of the teacher in drawing up the syllabus and the RPP is good increased by $52 \%$ and $58 \%$. The implementation of individual supervision is suitable to improve the competence of teachers in drawing up the syllabus and RPP during this Administration remains a difficult requested from our teachers. To test it, we can use the class supervision. For the other trustees are expected to give a clearer input and directional in formation against the teacher.
\end{abstract}

Keywords: Teacher Competencies, Syllabus, RPP, Academic Supervision.

\begin{abstract}
Abstrak
Penelitian ini untuk melihat persentasi supervisi akademik kepala sekolah dapat meningkatkan kompetensi guru dalam penyusunan silabus dan RPP. Lokasi penelitian adalah di SMK Negeri 4 Padangsidimpuan yang beralamat di Jln. Perkebunan Pijorkoling Desa Perkebunan Kec. Padangsidimpuan Tenggara Kota Padangsidimpuan. Waktu pelaksanaan direncanakan selama satu bulan mulai tanggal 1 s.d. 30 Oktober 2015. Penelitian ini dilaksanakan sendiri penulis, dan penulis dibantu oleh Tim Pengembang kurikulum SMK Negeri 4 Padangsidimpuan yang terdiri dari Kepala Sekolah, Waka Kurikulum, dan Waka Kesiswaan. Penelitian ini dilakukan dengan metode penelitian tindakan kelas yang berlangsung selama 2 siklus. Masing-masing siklus terdiri dari tahapan perencanaan, pelaksanaan, observasi dan refleksi. Hasil yang diperoleh yaitu meningkatnya jumlah silabus guru yang baik dari $31 \%$ menjadi $83 \%$

PeTeKa (Jurnal Penelitian Tindakan Kelas dan Pengembangan Pembelajaran) | 185
\end{abstract}


PeTeKa (Jurnal Penelitian Tindakan Kelas dan Pengembangan Pembelajaran)

Vol 1 No 3 Tahun 2018 Hal 185-191

setelah supervisi akademik. Selain itu jumlah RPP yang berkualitas baik juga meningkat dari $31 \%$ menjadi $89 \%$. Peningkatan kompetensi guru dalam menyusun silabus dan RPP yang baik meningkat sebesar 52\% dan 58\%. Pelaksanaan supervisi individual sangat cocok digunakan untuk meningkatkan kompetensi guru dalam menyusun silabus dan RPP yang selama ini masih menjadi administrasi yang masih sulit diminta dari guruguru kita. Untuk mengujinya, kita dapat menggunakan supervisi kelas. Untuk pengawas yang lain diharapkan dapat memberikan masukan yang lebih jelas dan terarah dalam pembinaan terhadap guru.

Kata Kunci: Kompetensi Guru, Silabus, RPP, Supervisi Akademik.

\section{PENDAHULUAN}

Guru yang profesional amat berarti bagi pembentukan sekolah unggulan. Guru profesional memiliki pengalaman mengajar, kapasitas intelektual, moral, keimanan, ketaqwaan, disiplin, tanggungjawab, wawasan kependidikan yang luas, kemampuan manajerial, trampil, kreatif, memiliki keterbukaan profesional dalam memahami potensi, karakteristik dan masalah perkembangan peserta didik, mampu mengembangkan rencana studi dan karir peserta didik serta memiliki kemampuan meneliti dan mengembangkan kurikulum.

Guru yang profesional adalah orang yang memiliki kemampuan dan keahlian khususnya dalam bidang keguruan, sehingga ia mampu melakukan tugas dan fungsinya sebagai guru dengan kemampuan maksimal (Usman, 2006). Tugas guru untuk menjadi guru profesional meliputi, mendidik, mengajar, dan melatih. Mendidik berarti meneruskan dan mengembangkan nilai-nilai hidup. Mengajar berarti meneruskan dan mengembangkan ilmu pengetahuan dan teknologi. Sedangkan melatih berarti mengembangkan keterampilan pada siswa (Mulyasa, 2011).

Dengan melihat pentingnya penyusunan perencanaan pembelajaran ini, guru semestinya tidak mengajar tanpa adanya rencana. Namun sayang perencanaan pembelajaran yang mestinya dapat diukur oleh kepala sekolah ini, tidak dapat diukur oleh kepala sekolah karena hanya direncanakan dalam pikiran sang guru saja. Akibatnya kepala sekolah sebagai pembuat kebijakan di sekolah tidak dapat mengevaluasi kinerja guru secara akademik. Kinerja yang dapat dilihat oleh kepala sekolah hanyalah kehadiran tatap muka, tanpa mengetahui apakah kemampuan guru dalam mengelola pembelajaran sudah sesuai dengan harapan atau belum, atau sudahkah kompetensi dasar yang harus dikuasai oleh siswa terkuasai dengan benar.

Hasil pengamatan di tahun pelajaran 2015/2016 di SMK Negeri 4 Padangsidimpuan didapatkan data yaitu Hanya $60 \%$ guru yang menyusun silabus dan RPP. Secara kualitas, silabus dan RPP yang baik baru mencapai angka 30\% dari silabus dan RPP yang dibuat oleh guru. Untuk mengatasi permasalahan tersebut, peneliti yang berkedudukan sebagai pengawas di atas merencanakan untuk melakukan supervisi akademik yang berkelanjutan. Dengan metode tersebut diharapkan setelah kegiatan, guru yang menyusun silabus dan RPP meningkat menjadi $90 \%$ dan kualitas silabus dan RPP yang baik menjadi 80\%."

Kompetensi adalah kemampuan, kecakapan, keadaan berwenang, atau 
memenuhi syarat menurut ketentuan hukum. Selanjutnya masih menurut Syah, dikemukakan bahwa kompetensi guru adalah kemampuan seorang guru dalam melaksanakan kewajibankewajibannya secara bertanggung jawab dan layak (Muhibbin, 2000). Merumuskan definisi kompetensi sebagai pengetahuan, keterampilan, dan nilai-nilai dasar yang direfleksikan dalam kebiasaan berfikir dan bertindak (Depdiknas, 2004). Kompetensi adalah seperangkat tindakan intelegen penuh tanggung jawab yang harus dimiliki seseorang sebagai syarat untuk dianggap mampu melaksankan tugastugas dalam bidang pekerjaan tertentu. Sifat intelegen harus ditunjukan sebagai kemahiran, ketetapan, dan keberhasilan bertindak. Sifat tanggung jawab harus ditunjukkan sebagai kebenaran tindakan baik dipandang dari sudut ilmu pengetahuan, teknologi maupun etika (Muhaimin, 2004). Kompetensi guru sebagai penguasaan terhadap pengetahuan, keterampilan, nilai dan sikap yang direfleksikan dalam kebiasaan berpikir dan bertindak dalam menjalankan profesi sebagai guru.

Menindaklanjuti permasalahan guru dalam menjalankan tugas profesional, pemerintah melakukan usaha perbaikan dengan memprogramkan kegiatan pengembangan kompetensi guru. Salah satu contoh kegiatan peningkatan kinerja guru yaitu melalui bantuan supervisor, orang yang melaksanakan kegiatan supervisi terhadap guru (Mukhtar \& Iskandar, 2010). Sagala (2010) menyatakan supervisi pendidikan adalah upaya perbaikan pengajaran sebagai langkah pertumbuhan jabatan profesional guru yang berintegrasi pada kebutuhan individu dengan tujuan pendidikan dan tugas-tugas pokok sekolah. Lebih khusus Sagala mendefinisikan supervisi akademik adalah untuk membantu guruguru belajar bagaimana meningkatkan kemampuan dan kapasitasnya, agar peserta didiknya dapat mewujudkan tujuan belajar yang telah ditetapkan.

Menurut Konsep supervisi tidak bisa disamakan dengan inspeksi, Inspeksi lebih menekankan kepada kekuasaan dan bersifat otoriter, sedangkan supervisi lebih menekankan kepada persahabatan yang dilandasi oleh pemberian pelayanan dan kerjasama yang lebih baik diantara guruguru, karena bersifat demokratis. Istilah supervisi pendidikan dapat dijelaskan baik menurut asal usul (etimologi), bentuk perkataannya (morfologi), maupun isi yang terkandung dalam perkataan itu (semantik).

\section{METODE}

Lokasi penelitian adalah di SMK Negeri 4 Padangsidimpuan yang beralamat di Jln. Perkebunan Pijorkoling Desa Perkebunan Kec. Padangsidimpuan Tenggara Kota Padangsidimpuan. Waktu pelaksanaan direncanakan selama satu bulan mulai tanggal 1 s.d. 30 Oktober 2015. Penelitian ini dilaksanakan sendiri penulis, dan penulis dibantu oleh Tim Pengembang kurikulum SMK Negeri 4 Padangsidimpuan yang terdiri dari Kepala Sekolah, Waka Kurikulum, dan Waka Kesiswaan.

Penelitian ini dilakukan dengan metode penelitian tindakan kelas yang berlangsung selama 2 siklus. Masingmasing siklus terdiri dari tahapan perencanaan, pelaksanaan, observasi dan refleksi. Metode penelitian yang dilakukan peneliti adalah dengan melaksanakan supervisi akademik yang meliputi supervisi tradisional dan supervisi klinis. 


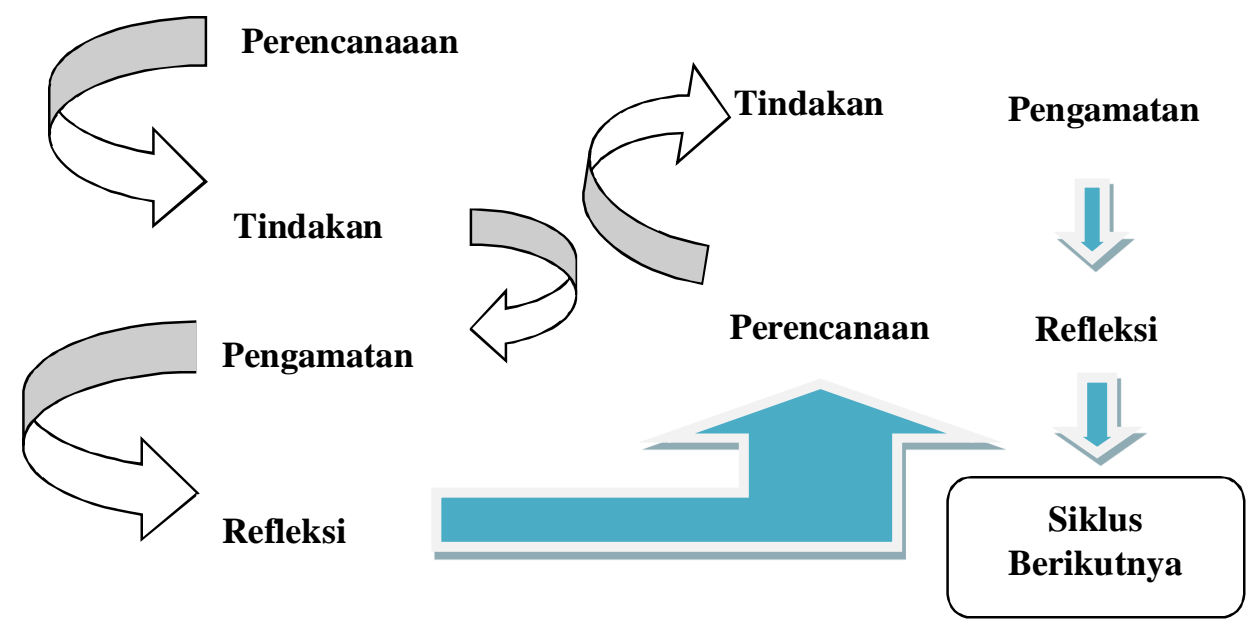

Gambar 1: Siklus Kegiatan Pelaksanaan Penelitian Tindakan Sekolah

\section{Rencana Tindakan Siklus 1 Perencanaan}

Pada tahap ini, peneliti merencanakan langkah-langkah sebagi berikut:

1. Mengidentifikasi jumlah guru yang sudah membuat silabus dan RPP

2. Meminta guru untuk mengumpulkan perangkat pembelajaran

3. Peneliti memeriksa administrasi guru secara kuantitas dan kulitatif.

4. Peneliti mengidentifikasi permasalahan yang ditemukan.

5. Menyusun rencana tindakan (berupa penjadwalan supervisi individual atau kelompok disesuaikan dengan temuan pada identifikasi masalah)

\section{Pelaksanaan}

$$
\text { Pada tahap ini peneliti }
$$

melaksanakan rencana tindakan supervisi individual/kelompok untuk menilai administrasi guru yang sudah dikumpulkan sebelumnya. Pelaksanaan supervisi dilakukan dengan pertemuan individual office-conference. Hal ini dilakukan terutama kepada guru yang tidak mengumpulkan perangkat pembelajaran, untuk mengetahui penyebab/masalahnya. Tahap ini peneliti rencanakan berlangsung selama
2 minggu dan dilaksanakan bersamasama dengan kolaborator.

\section{Observasi}

Pada tahap ini peneliti melakukan kegiatan observasi terhadap seluruh kejadian yang terjadi selama tahap pelaksanaan dan mengobservasi hasil awal yang dicapai pada pelaksanaan tindakan siklus 1. Selain itu peneliti juga mengidentifikasi masalah-masalah lanjutan yang timbul dari pelaksanaan tindakan di siklus 1 .

\section{Refleksi}

Pada tahap refleksi, peneliti melakukan evaluasi terhadap tindakan dan data-data yang diperoleh. Kemudian dilanjutkan dengan pertemuan bersama kolaborator untuk membahas hasil evaluasi dan penyusunan langkah-langkah untuk siklus kedua.

\section{Rencana Tindakan Siklus 2 Perencanaan}

Tahap perencanaan pada siklus kedua ini, peneliti melakukan pertemuan dengan kolaborator untuk menyusun penjadwalan supervisi kelas 
Budiman Sihombing. Upaya Peningkatan Kompetensi Guru Dalam Menyusun ...

dan menyiapkan instrumen supervisi untuk siklus kedua.

\section{Pelaksanaan}

Pada tahap ini, guru-guru yang sudah siap perangkat perencanaan pembelajarannya disupervisi kelas oleh peneliti. Hal ini untuk melihat kesesuaian perencanaan pembelajaran dengan pelaksanaan pembelajaran.

\section{Observasi}

Di tahap observasi siklus kedua, peneliti mengobservasi kesesuaian perencanaan pembelajaran dengan pelaksanaan pembelajaran serta melihat keberterimaan siswa dalam proses belajar mengajar. Pada tahap ini pula, peneliti mengumpulkan data-data yang terjadi selama tahap pelaksanaan.

\section{Refleksi}

Pada tahap refleksi siklus kedua, peneliti melakukan evaluasi bersama guru yang disupervisi terhadap hasil observasi di siklus kedua.

\section{HASIL DAN PEMBAHASAN}

Hasil perhitungan perangkat pembelajaran yang dikumpulkan dapat dilihat pada table:

Tabel 1: Daftar Setoran Perangkat Pembelajaran Tahun Pelajaran 2015/2016

\begin{tabular}{|c|c|c|c|c|c|c|c|}
\hline \multirow[b]{2}{*}{ No } & \multirow[b]{2}{*}{ Mata Pelajaran } & \multicolumn{3}{|c|}{ SILABUS } & \multicolumn{3}{|c|}{ RPP } \\
\hline & & $\underset{\text { TKR }}{\mathbf{X}}$ & $\begin{array}{c}\text { XI } \\
\text { TKR }\end{array}$ & $\begin{array}{r}\text { XII } \\
\text { TKR }\end{array}$ & $\underset{\text { TKR }}{\mathbf{X}}$ & $\begin{array}{c}\text { XI } \\
\text { TKR }\end{array}$ & $\begin{array}{c}\text { XII } \\
\text { TKR }\end{array}$ \\
\hline & Kelompok Normatif & & & & & & \\
\hline 1 & Pendidikan Agama & $\mathrm{v}$ & $\mathrm{v}$ & $\mathrm{v}$ & $\mathrm{v}$ & & \\
\hline 2 & Pendidikan & & & & & & \\
\hline 2 & Kewarganegaraan & $\mathrm{v}$ & $\mathrm{v}$ & $\mathrm{v}$ & $\mathrm{v}$ & $\mathrm{v}$ & $\mathrm{v}$ \\
\hline 3 & Bahasa Indonesia & $\mathrm{v}$ & $\mathrm{v}$ & $\mathrm{v}$ & $\mathrm{v}$ & $\mathrm{v}$ & $\mathrm{v}$ \\
\hline 4 & Pendidikan & & & & & & \\
\hline 4 & Olahraga dan kesehatan & $\mathrm{v}$ & $\mathrm{v}$ & $\mathrm{v}$ & $\mathrm{v}$ & $\mathrm{v}$ & $\mathrm{v}$ \\
\hline 5 & $\begin{array}{l}\text { Seni Budaya } \\
\text { Kelompok Adaftif }\end{array}$ & $\mathrm{v}$ & $\mathrm{v}$ & $\mathrm{v}$ & $\mathrm{v}$ & $\mathrm{v}$ & $\mathrm{v}$ \\
\hline 1 & Matematika & $\mathrm{v}$ & $\mathrm{v}$ & & $\mathrm{v}$ & $\mathrm{v}$ & \\
\hline 2 & Bahasa Inggris & $\mathrm{v}$ & $\mathrm{v}$ & $\mathrm{v}$ & $\mathrm{v}$ & $\mathrm{v}$ & $\mathrm{v}$ \\
\hline 3 & KKPI & $\mathrm{v}$ & $\mathrm{v}$ & $\mathrm{v}$ & $\mathrm{v}$ & $\mathrm{v}$ & $\mathrm{v}$ \\
\hline 4 & Kewirausahaan & & & & & & \\
\hline 5 & IPS & $\mathrm{v}$ & $\mathrm{v}$ & $\mathrm{v}$ & $\mathrm{v}$ & $\mathrm{v}$ & $\mathrm{v}$ \\
\hline 6 & IPA & $\mathrm{v}$ & $\mathrm{v}$ & $\mathrm{v}$ & $\mathrm{v}$ & $\mathrm{v}$ & $\mathrm{v}$ \\
\hline 7 & Fisika & $\mathrm{v}$ & $\mathrm{v}$ & & $\mathrm{v}$ & $\mathrm{v}$ & \\
\hline 8 & $\begin{array}{l}\text { Kimia } \\
\text { Kelompok Produktif }\end{array}$ & $\mathrm{v}$ & $\mathrm{v}$ & & $\mathrm{v}$ & $\mathrm{v}$ & \\
\hline 1 & Kompetensi & & & & & & \\
\hline & Kejuruan & $\mathrm{v}$ & $\mathrm{v}$ & $\mathrm{v}$ & $\mathrm{v}$ & $\mathrm{v}$ & $\mathrm{v}$ \\
\hline 2 & $\begin{array}{lr}\text { Kompetensi } & \text { Kejuruan } \\
\text { Teknik } & \text { Kendaraan }\end{array}$ & & & & & & \\
\hline & Ringan & $\mathrm{v}$ & $\mathrm{v}$ & $\mathrm{v}$ & $\mathrm{v}$ & $\mathrm{v}$ & $\mathrm{v}$ \\
\hline
\end{tabular}


PeTeKa (Jurnal Penelitian Tindakan Kelas dan Pengembangan Pembelajaran)

Vol 1 No 3 Tahun 2018 Hal 185-191

Tabel 2: Rekapitulasi Penilaian Silabus Dan RPP

\begin{tabular}{lllcc}
\hline No & Klasifikasi Penilaian & Rentang Nilai & f & \% \\
\hline A. & SILABUS & & & \\
1 & A : Baik sekali & $86-100$ & - & - \\
2 & B : Baik & $71-85$ & 5 & 28 \\
$3 \quad$ C : Cukup & $51-70$ & 11 & 61 \\
$4 \quad$ D : Kurang & $0-50$ & 2 & 11 \\
Jumlah & & $\mathbf{1 8}$ & $\mathbf{1 0 0}$ \\
Prosentase A dan B & & $\mathbf{2 8}$ & \\
\hline B. RPP & & & \\
$1 \quad$ A : Baik sekali & $86-100$ & - & - \\
$2 \quad$ B : Baik & $71-85$ & 8 & 44 \\
$3 \quad$ C : Cukup & $51-70$ & 8 & 44 \\
$4 \quad$ D : Kurang & $0-50$ & 2 & 11 \\
Jumlah & & $\mathbf{1 8}$ & \\
Prosentase A dan B & & $\mathbf{4 4}$ & \\
\hline
\end{tabular}

Tabel 3: Hasil Penilaian Supervisi Kelas

\begin{tabular}{llccc}
\hline No & $\begin{array}{c}\text { Klasifikasi } \\
\text { Penilaian }\end{array}$ & Rentang nilai & f & \% \\
\hline 1 & A : Sesuai & $76-100$ & 15 & 83 \\
2 & B : Cukup sesuai & $51-75$ & 3 & 17 \\
3 & C : Kurang sesuai & $26-50$ & - & - \\
4 & D : Tidak sesuai & $0-25$ & - & - \\
& & & 18 & 100 \\
\hline
\end{tabular}

Hasil dari analisa penguat tersebut, menunjukkan bahwa silabus dan RPP yang dikumpulkan benar disusun oleh guru yang bersangkutan. Karena terjadi kesesuaian scenario antara perencanaan dan pelaksanaan di kelas. Supervisi akademik secara berkelanjutan terbukti secara ilmiah dapat meningkatkan kompetensi guru dalam menyusun silabus dan RPP di SMK Negeri 4 Padangsidimpuan. Ini terbukti dengan meningkatnya jumlah silabus guru yang baik dari $31 \%$ menjadi $83 \%$ setelah supervisi akademik. Selain itu jumlah RPP yang berkualitas baik juga meningkat dari $31 \%$ menjadi $89 \%$.
Langkah-langkah yang mengakibatkan terjadinya peningkatan kompetensi guru dalam menyusun silabus dan RPP tersebut meliputi langkah-langkah: (1) Pengumuman rencana supervisi terhadap guru, (2) Pelaksanaan supervisi individual, dimana setiap guru diminta mempresentasikan silabus dan RPP-nya kepada kepala sekolah, kemudian kepala sekolah memberikan masukan terhadap kekurangan silabus dan RPP guru, (3) Untuk mengecek originalitas silabus dan RPP yang disusun guru, kepala sekolah melakukan supervisi kelas. Hal ini dilakukan untuk menyesuaikan rencana yang dimuat 
Budiman Sihombing. Upaya Peningkatan Kompetensi Guru Dalam Menyusun ...

dalam silabus dan RPP dengan penerapannya di kelas. Jika sesuai maka dapat dipastikan, kompetensi guru dalam menyusun silabus dan RPP tersebut benar (bukan jiplakan atau dibuatkan orang lain). Jika banyak ketidaksesuaian maka ada kemungkinan silabus dan RPP tersebut dibuatkan oleh orang lain.

Peningkatan kompetensi guru dalam menyusun silabus dan RPP yang baik meningkat sebesar $52 \%$ dan $58 \%$. Pelaksanaan supervisi individual sangat cocok digunakan untuk meningkatkan kompetensi guru dalam menyusun silabus dan RPP yang selama ini masih menjadi administrasi yang masih sulit diminta dari guru-guru kita. Untuk mengujinya, kita dapat menggunakan supervisi kelas. Untuk pengawas yang lain diharapkan dapat memberikan masukan yang lebih jelas dan terarah dalam pembinaan terhadap guru.

\section{SIMPULAN}

Dari pelaksanaan tindakan mulai dari Siklus I sampai Siklus II didapati kenyataan bahwa meningkatnya jumlah silabus guru yang baik dari $31 \%$ menjadi $83 \%$ setelah supervisi akademik. Selain itu jumlah RPP yang berkualitas baik juga meningkat dari $31 \%$ menjadi $89 \%$. Peningkatan kompetensi guru dalam menyusun silabus dan RPP yang baik meningkat sebesar $52 \%$ dan $58 \%$.

\section{DAFTAR PUSTAKA}

Depdiknas. 2004. Standar Kompetensi Guru Sekolah Dasar Jakarta: Depdiknas.

Muhaimin. 2004. Paradigma Pendidikan Islam. Bandung: PT. Remaja Rosda Karya.

Mukhtar \& Iskandar. 2009. Orientasi Baru Supervisi Pendidikan. Jakarta: Gaung Persada Press.

Mulyasa, E., 2011. Menjadi Guru Profesional . Bandung: PT. Remaja Rosda Karya.

Sagala, S. 2010. Supervisi Pembelajaran dalam Profesi Pendidikan. Bandung: Alfabeta.

Syah, M. 2000. Psikologi Pendidikan Dengan Pendekatan Baru. Bandung: PT. Remaja Rosda Karya.

Usman, M. U., 2006. Menjadi Guru Profesional. Bandung: PT. Remaja Rosda Karya. 